\title{
THE NEW ZEALAND JOURNAL OF HISTORY
}

\section{EDITOR: Keith Sinclair}

\section{FORTHCOMING ARTICLES}

HELEN TAFT MANNING Lord Durham and New Zealand

JOHN A. MOSES

R. ARNOLD

KATHRYN PETERS

IAN C. MacGIBBON
The Solf Regime in Western Samoa

English Rural Unionism and Taranaki Immigration, $1871-1876$

New Zealand's Attitude to the Reform of the League of Nations

Constitutional Implications of Lord Jellicoe's Influence upon New Zealand Naval Policy, 1919-1930

Annual subscription NZ\$4.00, A $\$ 4.50$, US\$5.00, $£ 2.10$ sterling.

Published twice yearly by the University of Auckland, Private Bag,

AUCKLAND, New Zealand. 


\section{JOURNAL OF SOUTHEAST ASIAN STUDIES}

The Journal of Southeast Asian Studies, is published for the Department of History, University of Singapore by McGraw-Hill Far Eastern Publishers (S) Limited in March and September.

Articles in the Journal of Southeast Asian Studies do not represent the views of the Editors or those of the publisher. The Editor is responsible for the final selection of the content of the Journal and reserves the right to reject any material deemed inappropriate for publication. Responsibility for opinions expressed and for the accuracy of facts published in articles rests solely with the individual authors.

Requests for permission to reprint articles should be directed to the Editor. Articles appearing in this journal are abstracted and indexed in ABC POL SCI, HISTORICAL ABSTRACTS and/or AMERICA: HISTORY AND LIFE.

\section{CONTRIBUTIONS}

Contributions are invited from all scholars, especially those working in Southeast Asian universities and research institutions. The length of articles should preferably be between 4000 and 8000 words. Progress reports on research projects, notes on conferences, and comments on institutions devoted to Southeast Asian studies are also welcomed. All contributions should be typewritten or mimeographed, with double-spacing, and submitted in duplicate.

Each contributor will receive 30 offprints of his/her article and a complimentary copy of the Journal.

Editorial correspondence and contributions should be directed to

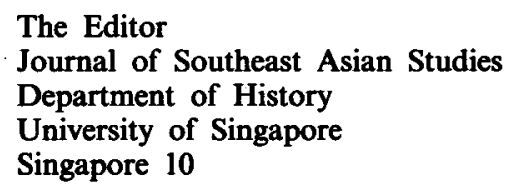

\section{Subscriptions}

Subscription rates are as follows:

Price: $\$ \$ 8.50$ per copy (by surface mail)

2nd class airmail add:

U.S.A.

U.K./Europe

Australia/N.Z.

S. America

Africa

Asia
S\$8.50 per copy

S\$7.50 per copy

S\$5.00 per copy

\$\$8.50 per copy

S\$7.50 per copy

$\$ \$ 5.00$ per copy

Subscriptions and all business correspondence should be addressed to:

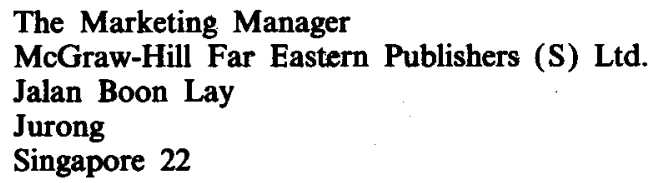




\section{CONTRIBUTORS TO THIS ISSUE}

J.E. HOFFMAN is an editorial and feature writer with a Melbourne newspaper. He has recently completed a Master's thesis entitled "The Exercise of Power in the Straits of Malacca after 1641". Currently he is working on the role of the Malay Language in the Shaping of Indonesia.

ROBERT B. CRUIKSHANK is a PhD candidate in the History Department, University of Wisconsin. Madison. He is working on the history of Samar Island, Philippines during the eighteenth and nineteenth centuries.

JERRY M. SILVERMAN is Assistant Professor in the Department of Political Science, McMaster University. Ontario.

MARTIN RUDNER is a Research Fellow at the Institute of Asian and African Studies at the Hebrew University of Jerusalem. He is Editor of Society and Development in Asia and has written various articles on aspects of Malayan economy. His current research project is on the Politics and Economics of Educational Development in West Malaysia and Singapore since 1945.

DEREK McDOUGALL is a PhD candidate in Political Science at Duke University. His dissertation is on Harold D. Lasswell and his contribution to the study of World Politics.

R.S. MILNE is Professor of Political Science at the University of British Columbia, Vancouver. His major publication is Government and Politics in Malaysia and he is the co-author (with K.J. Ratnam) of The Malayan General Election of 1964 and a forthcoming publication entitled New States in a New Nation: Sarawak and Sabah inside Malaysia.

K.J. RATNAM, Dean of the School of Comparative Social Sciences, University of Penang is best known for his book Communalism and the Political Process in Malaya.

DAVID F. ROTH is Assistant Professor in the Department of Political Science, and also Director of the Asian Political Performance Institute at Purdue University, Lafayette. He is the joint author of a forthcoming book entitled Introduction to Comparative Politics. His current research is on Political Performance and Strategies of Rural Change and Industrialization in Asian Nations. 